\title{
RESEARCH PAPER \\ Effect of fire on herbaceous "matorral" vegetation of Central Chile
}

\author{
Patricia Sabadin, Miguel Gómez, Rosanna Ginocchio, Iván Peña, Ana María \\ Mujica, and Gloria Montenegro
}

Facultad de Agronomía e Ingeniería Forestal, Pontificia Universidad Católica de Chile. Vicuña Mackenna 4860, Macul, Santiago, Chile.

\begin{abstract}
P. Sabadin, M. Gómez, R. Ginocchio, I. Peña, A. M. Mujica, and G. Montenegro. 2015. Effect of fire on herbaceous "matorral" vegetation of Central Chile. Cien. Inv. Agr. 42(3): 415-425. This research aimed to determine the diversity and biomass of species in burned in the Jardín Botánico Nacional of Viña del Mar (JBN), region of Valparaíso, Chile (Lat. S $33^{\circ} 02^{\prime}$ and Long. $71^{\circ} 35^{\prime}$ O) from April to December 2012. Three sites were selected that were located on slopes with the same exposure: 1) site burned by fire in 2012,2) site burned by fire in 2003, and 3) control site corresponding to an area without previous fires. Both shrub and herbaceous species were studied. The cover of shrubs, geophytes and therophytes was determined as well as the aboveground and belowground biomass of geophytes, with special attention paid to Oziroe arida. When $O$. arida was present, the diameter of its bulbs were studied. All information was processed by SAS software with ANOVA - analysis of 2 WAYS classification., The extensive geophyte coverage that exists in the site that was burned by fire in 2012 is due to the increased post-fire regeneration of this life-form. The biomass of geophytes is greater in the burned areas, especially during the first year after the fire (2012 site). On the site that burned in 2003, there was a higher percentage of therophyte coverage; there was no relationship found between the coverage of therophytes and the coverage of woody plants. It was determined that for each additional millimeter of diameter, there is an increase in age of 2.99 years for Oziroe arida bulbs, the most abundant geophyte in the site $1\left(\mathrm{R}^{2}=0.78\right)$; that is, the bulb diameter will be an indicator of the age of the bulbs. This study represents the first in the country to perform a quantitative analysis of the behavior of geophytes after fires (aboveground and belowground biomass), and it concluded that the action of fire favors the regeneration of geophytes through the generation of further overhead and underground biomass, which created conditions for increased reproduction.
\end{abstract}

Key words: Aboveground biomass, belowground biomass, cover, fires, geophytes, Oziroe arida, shrub species, therophytes.

\section{Introduction}

Central Chile is one of the five regions of the world that has a Mediterranean climate. It is characterized by dry summers and wet winters

Received May 13, 2014. Accepted November 4, 2015. Corresponding author: pcsabadi@gmail.com (di Castri, 1981; Groves and di Castri, 1991; Rundel, 1998). Additionally, due to its high levels of endemism, biodiversity and human impact, such as forest fires, it has been described as a biodiversity hotspot (Myers et al., 2000).

The plants of this region have adapted to survive the periods of low rainfall using different 
strategies; some avoid the drought and others support it. The aerial parts of some plants dry out and only their seeds remain during the unfavorable season, germinating in the following spring (annual grasses), whereas some plants survive the dry season by having underground stems, such as bulbs, rhizomes and tubers, that store water and nutrients (Montenegro, 1984).

The predominant vegetation in the Mediterranean area of Central Chile corresponds to matorral, which is a naturally sclerophyllous vegetation adapted to a harsh environment that includes an extended period of drought and low levels of nutrients available in the soil (Montenegro et al., 1981; Montenegro et al., 2003).

Today, Central Chile is highly influenced by human activities (Montenegro, 1986; Montenegro, 2000). Most of the Chilean population lives between the regions of Valparaíso and La Araucanía (Arroyo and Cavieres, 1997; Matthei, 1995); therefore, this area has the highest population density. The main human impacts include: fires, overgrazing by goats, clearing forest for firewood and charcoal and the replacement of native vegetation with agricultural fields and forest plantations (Montenegro, 2000).

The annual number of fires in Chile has increased over time from 500 fires per year in 1963-64 to 5,500 per year in 1997-98 (Fernández et al., 2010). The Central zone of Chile follows the same national trend. During the period 19872007, 1,200 fires occurred on average in the region of Valparaíso. This region of Chile is the second highest regarding the average number of fires, after the region of Bio-Bío (2300 fires) (Fernandez et al., 2010).

Fire is an important ecological force in countries that have a Mediterranean climate. In these areas, most plant communities are resistant to wildfires, and many species have developed adaptations to periodic fires (Keeley and Keeley, 1986). In all Mediterranean ecosystems, many woody and herbaceous species are able to recover after forest fires through the regrowth of vegetative structures under the ground, but regrowth is a widespread characteristic in plants and, most likely, it is a preadaptation process to survive fires (Wells, 1969).

In the matorral of Central Chile, species resprout after a fire but fail to recruit seedlings in the postfire environment (Keeley, 1995). Specifically, most of the woody species can resprout after fire (Mooney, 1977; Araya and Ávila, 1981; Montenegro et al., 1983) from modified underground roots or stem crowns (lignotubers) (Mooney, 1977, Montenegro et al., 1983; Montenegro and Ginocchio, 1995). No seedling recruitment is observed during the first growing season after a fire, which is different from the other four Mediterranean climate regions in the world (Keeley, 1995).

The geophyte diversity that occurs within these Mediterranean ecoregions is probably linked to the seasonality of rainfall and the occurrence of fires, which promote resource acquisition and limit the competition from shrubs and grasses, respectively. Geophyte abundance could also be attributed to their adaptation to fire, represented by a dormant period during the fire season, whereby, geophytes are well protected against fire (Rundel, 1981; Le Maitre and Midgley, 1992; Montenegro et al., 2003). These plants survive fires because their bulbs, corms, or rhizomes are buried deep enough to not be destroyed by the high temperatures of the soil surface (Keeley and Keeley, 1988; Montenegro et al., 2003; Montenegro et al., 2004).

Several studies in other Mediterranean regions have demonstrated a similar response of geophytes to fire, suggesting that fire increases the shortterm availability of resources, specifically light and nutrients, and reduces the competition with surrounding vegetation (Le Maitre and Midgley, 1992; Blair, 1997). Although few experimental studies have been conducted to this respect (Tyler 
and Borchert, 2002), the factors that have been found to stimulate flowering include direct effects (e.g., heat, smoke, the addition of chemicals), and indirect fire effects (e.g., soil nutrient increases, increases of light levels due to the removal of bushes, and the removal of other inhibitors) (Stone and Juhren, 1951; Keeley et al., 1981; Keeley, 1993; Johnson et al., 1994).

Blooming triggered by smoke has never been described for any Chilean geophyte, but greater flowering after a fire has been mentioned by some authors (Hoffmann et al., 1998; Montenegro et al, 2003; Montenegro et al., 2004) for some species of the genus Alstroemeria.

As the shrub canopy closes over time, geophytes, unlike most other post-fire herbaceous species, remain in the understory. They can bloom either sporadically or rarely, but it has been suggested that in mature communities geophytes likely decrease productivity and can be dormant (Keeley and Keeley, 1988; Parker and Kelly, 1989).

Research on geophytes in Chile, in general, and their responses to fire, in particular, is scarce. Because the greatest diversity of geophytes is found in the Mediterranean, and because $70 \%$ of them are endemic in Chile (Hoffmann et al. 1998), it is necessary and important to understand the responses that these species have developed to survive and thrive in this environment, especially concerning their adaptations and responses to fire.

After a fire in the Chilean matorral, the ground coverage of geophytes increases, but it is not known what happens to geophytes as the scrub recovers to its normal level. The objective of this study was to determine the diversity and the abundance of shrubs, geophytes and therophytes in the herbaceous layer of the Chilean matorral in a protected area of the region of Valparaíso by comparing both parameters in three successional stages after burning.

\section{Materials and methods}

\section{Study sites}

The study was conducted in a coastal matorral community located in a protected area belonging to the Jardín Botánico Nacional (JBN) in the region of Valparaíso, Chile (Figure 1) (Latitude $33^{\circ} 02^{\prime} \mathrm{S}$ and Longitude $71^{\circ} 35^{\prime} \mathrm{W}$ ) from April to December 2012. The climate in this area is Mediterranean Pluvistational-oceanic, where precipitation mainly occurs in winter, with water stress in the summer (Luebert and Pliscoff, 2005). The dominant species are Azara celastrina, Baccharis concava, Baccharis linearis, Escallonia pulverulenta, Lithrea caustica, Puya chilensis, Quillaja saponaria and Schinus latifolius. The herbaceous vegetation includes: Conanthera trimaculata, Dioscorea humifusa, Oziroe arida, Pasithea coerulea, Ayra caryopphyllea, and Vulpia myuros.

In this community, three sites were selected in areas located according to the records for fire provided by the JBN and containing information since the year 1998. Such records contain information relating to the date of the fire, its point of origin and the area burned. Because the perimeter of the fire was not clearly defined, it was assumed that each fire covered a circular area. The center of the circle was stablished as a function of the origin point of the fire, where A is the burned area, $\pi$ : 3.1416 and $\mathrm{r}$ is the radius, in meters (A $\left.=\pi \times \mathrm{r}^{2}\right)$. Furthermore, using ArcGIS program (ESRI, California, USA), the slope exposures were determined. The area burned by fires and exposure of the slopes were projected onto an aerial photo provided by the JBN. With this background, three study sites were chosen: Site 1: burned in February of 2012, and no record of previous occurrence of fires; Site 2: burned in 2003 and no record of previous or subsequent fires: Site 3: control without the occurrence of previous fires (Figure 1).

At each site analyzed, the diversity and abundance of shrubs and herbaceous vegetation was determined. 


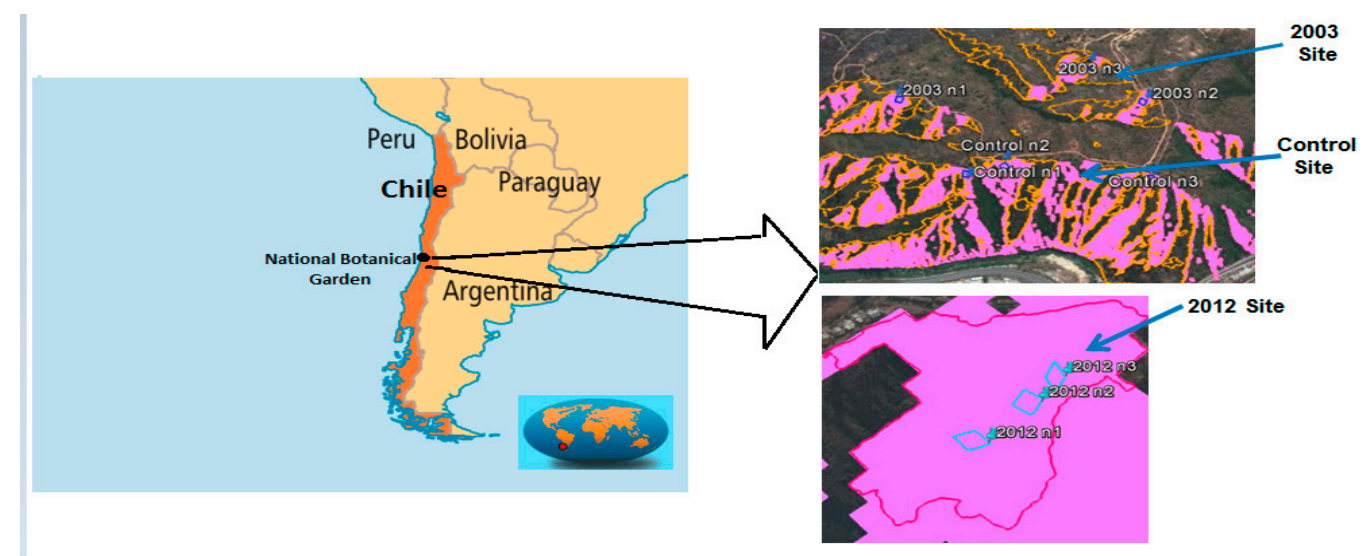

Figure 1. Map showing Chile and the location of the study sites.

\section{Sampling of vegetation}

For the vegetation study, three $25 \times 25$ m quadrats were delineated in each of the 3 sampling sites (in the control area as well as in the 2 burned sites). The quadrats were randomly selected and located in zones with better access (Figure 2). Each quadrat was subdivided into a $5 \times 5 \mathrm{~m}$ grid.

\section{Sampling for shrub vegetation}

Shrub vegetation was sampled in quadrats within four randomly selected $5 \times 5 \mathrm{~m}$ grids (Figure 2), which was used to determine the specific diversity by calculating the different amounts of coverage. The calculation was made using the method of intercepted line (Kent and Coker, 1994). For this method, two transects of the intercepted line were traced for each of the $5 \mathrm{~m}$-long grids.

\section{Sampling for herbaceous vegetation}

The herbaceous vegetation was sampled at four random points in the intersection of the $5 \times 5$ meter grid, and a $60 \times 60 \mathrm{~cm}$ grid was placed at these random points, without replacement (Figure 2). There were 16 points (small circles) within the $25 \times 25 \mathrm{~m}$ quadrat. The four points randomly chosen correspond to $25 \%$ of the
16 points within the quadrat and represent a high percentage of each selected quadrat. The herbaceous cover within the $60 \times 60 \mathrm{~cm}$ grid was calculated according to the frequency (Figure 2) (Mostacedo and Fredericksen, 2000). The frequency estimate used to trace the outline of the herbaceous cover was performed according to Kent and Coker (1994).

\section{Sampling for geophytes}

In the three study sites, the aerial and underground biomass of geophytes was determined, for which $60 \times 60 \times 30 \mathrm{~cm}$ cubes of dirt were extracted from each of the 36 surveyed squares. Underground stems were extracted with their aerial parts and separated by species and were then deposited in paper bags that were labeled to identify the species and the study site. The bags were carried to the laboratory and dried in an oven at $25^{\circ} \mathrm{C}$ (with care taken not to burn the samples) until a constant weight was achieved. Once dry, the species were weighed on a precision balance.

Due to the dominance of the species Oziroe arida, this geophyte was studied and the diameter of its bulbs were recorded. The bulbs were collected at the site of the 2012 fire. The diameter was measured on 25 bulbs that were chosen at random. In addition, the cataphylls were used 


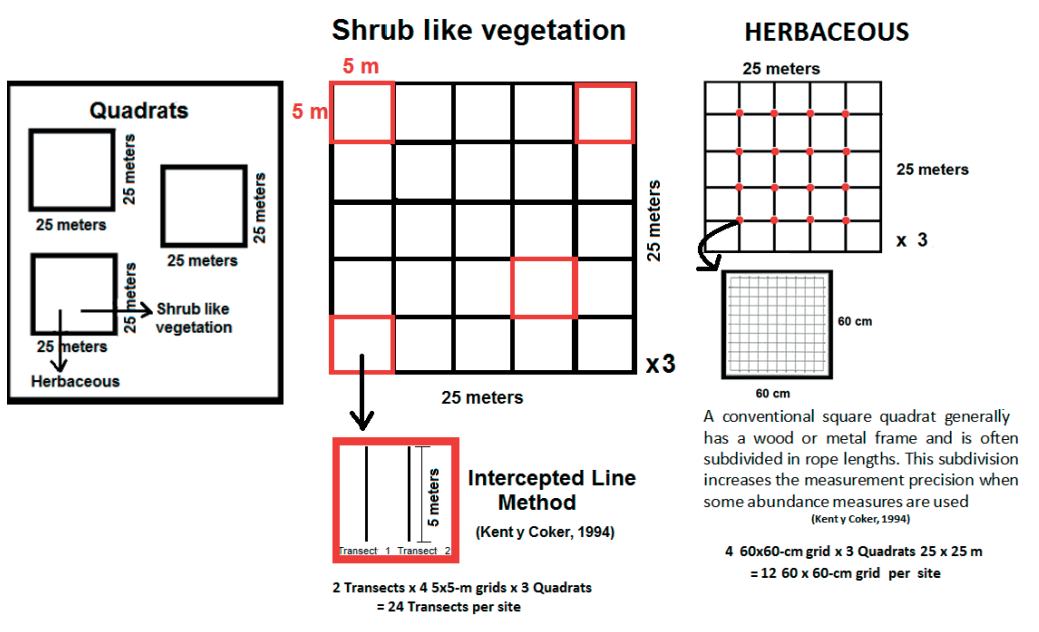

Figure 2. Quadrats used in the vegetation study, quadrats used for quantification of shrub vegetation, and quadrats used for quantification of herbaceous species.

to estimate the age of each bulb. According to Montenegro (1974), each cataphyll indicates a period of two years, plus one more year for the meristem. A regression analysis of age and bulb diameter was performed.

\section{Statistical analysis}

Because of the concern of potential bias due to a pseudoreplicate (because it is not possible to replicate fires), the interaction term (years) and vegetation (geophytes, therophytes and woody plants) were evaluated, made by study site. An analysis of variance with 3 observations per group was analyzed with a 2-way ANOVA, where the fixed factors were the primary sites (Control, 2003 and 2012) and the herbaceous shrub vegetation (geophytes, therophytes and woody plants). Mean comparisons (Tukey, $\mathrm{P} \leq 0.05$ ) and correlations (Pearson) were performed with the data. The Pearson correlation analysis was used to determine the degrees of association between shrubby herbaceous vegetation (geophytes and therophytes) and woody vegetation. To study bulb age, a regression analysis was used where the explanatory variable was bulb diameter. The regression analysis indicated a simple linear regression model because the growth in the observation period was always increasing. SAS software (SAS system, V9, Institute Inc., Cary, NC, USA) was used for the statistical analyses.

\section{Results and discussion}

\section{Total number and coverage of species per site}

In relation to the total average species richness per site, a significant difference was not found between the study sites (2012 site: 18 species, 2003 site: 17 species and control site: 14 species) $(\mathrm{P}=0.3002)$. These results support similar studies, such as Ávila et al. (1981), who did not find significant differences for species richness between burned sites and the control site in the Chilean Coastal Range.

Both hemicryptophyte and chamaephyte species had a low representation in the three studied sites (only one plot out of 3 plots for each site).

When comparing the species coverage of woody vegetation, geophytes and therophytes (Table 1), there were significant differences among the sites $(\mathrm{P} \leq 0.0001)$ (hemicryptophyte and chamaephyte species were not included, in accordance with their low levels of representation). 
Table 1. Cover of woody species and cover of geophyte and therophyte species (\%).

\begin{tabular}{lcccc}
\hline $\begin{array}{l}\text { Studied } \\
\text { sites }\end{array}$ & Geophytes & Therophytes & $\begin{array}{c}\text { Woody } \\
\text { plants }\end{array}$ & $\begin{array}{c}\text { Average } \\
\text { total } \\
\text { sites }\end{array}$ \\
\hline 2012 & $16.68 \mathrm{bB}$ & $5.63 \mathrm{aA}$ & $30.93 \mathrm{aC}$ & 16.13 \\
& & & 57.32 & \\
2003 & $6.89 \mathrm{aA}$ & $15.62 \mathrm{bB}$ & $\mathrm{bC}$ & 22.83 \\
Control & $4.97 \mathrm{aA}$ & $5.72 \mathrm{aA}$ & $89.00 \mathrm{cB}$ & 32.18 \\
$\begin{array}{l}\text { Average } \\
\text { overall }\end{array}$ & & & & \\
life style & 8.88 & 8.45 & 59.08 & 23.30 \\
\hline
\end{tabular}

Capital letters compare different life forms and small letters compare differences between sites. Tukey test $(\mathrm{P} \leq 0.05)$.

The geophyte cover increased notably in site 1 (burned in 2012) compared with the control site (Table 1). In Chile, geophyte growth can be determined by soil temperature instead of humidity, according to Villaseñor and Sáiz (1990). Additionally, the use of fire to eliminate vegetation and vegetal remains covering the soil diminishes competition and creates temperature and light conditions that are favorable for herbaceous development in the subsequent growth season. Several studies conducted in other Mediterranean ecoregions have shown a similar geophyte response to fire, suggesting that fire increases the short term availability of resources, particularly light and nutrients, and that fire reduces competition with the surrounding vegetation (Le Maitre and Midgley, 1992; Blair, 1997; Tyler and Brochert, 2002).

Significant differences that were found between the 2012 and 2003 sites can be explained because geophyte species cannot compete with the dominant shrub vegetation; therefore, growth conditions are optimal after a fire (Keeley, 1995). As the canopy of shrub vegetation closes over time, geophyte species are maintained in the understory, unlike most of the other post-fire herbaceous species. The geophyte species in mature communities most likely experience diminished activity and remain latent (Keeley and Keeley, 1988; Parker and Kelly, 1989).

The highest percentage of therophyte cover occurred in the 2003 site and was significantly different than the other treatments (Table 1). There were no significant differences for the therophyte cover between the 2012 site and the control site, which may be explained by the non-refractory-type seeds in the matorral of Central Chile. These seeds do not germinate when induced by fire, and they are burned during the event (Muñoz and Fuentes, 1989; Jiménez and Armesto, 1992). New seeds that were induced to begin their development, possibly by the effects of winter rains, have not germinated yet in the 2012 site.

The woody vegetation cover in the 2012 site (site 1), 2003 site, and the control site was significantly different. The lowest woody vegetation cover appeared in the site that burned in 2012 (30.9\%), which was significantly greater than the area burned in 2003 (57.3\%), and in the control site (89.0\%) where fires did not occur.

Furthermore, when comparing life forms, significant differences appeared between the therophyte cover and the woody vegetation cover at all of the sites studied. The highest percentage of therophyte cover occurred in the 2003 site (site 3), in accordance with the partial shading of $57 \%$ that may enable the development of an herbaceous stratus that could be restricted under conditions of total shading, which occurs in $89 \%$ of the control site (Table 1).

After a fire, there is a 1st stage of dominance of geophytes related to the decrease in woody vegetation coverage. The correlation between geophyte and woody species was $r=-0.80$, which was statistically significant $(\mathrm{P}=0.0099)$. As the woody vegetation cover increases, the geophyte cover decreases, as shown in Figure 3. Geophyte species cannot compete with the dominant shrub vegetation; therefore, growth conditions are optimal after a fire. Corms, bulbs and tubers reliably re-establish after a fire; they are deeply buried and therefore not subject to damage by fire or predation between fires. The subsequent postfire years are optimal for seedling recruitment. Therefore, these life forms have not produced refractory seeds (Keeley, 1995). 


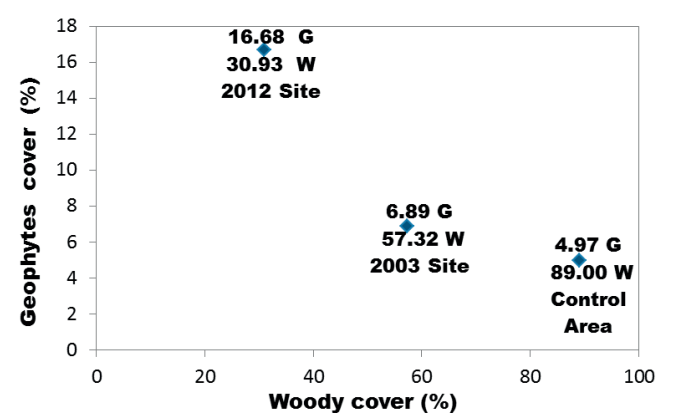

Figure 3. Variations of the geophyte cover with the woody species cover in percentages.

As the matorral canopy closes over time, geophyte species are maintained in the understory, unlike most other herbaceous post-fire species. They may bloom sporadically, but some authors suggest that geophyte species in mature communities most likely have diminished productivity and remain latent (Keeley and Keeley, 1988; Parker and Kelly, 1989).

The therophyte cover in the 2003 site (Figure 4) cannot be explained by the cover of woody vegetation in that site. Post-fire colonization is a complex process that depends on many factors, especially fire intensity and frequency and seed source (Figueroa et al., 2009). The seed sources would explain the higher percentage of therophyte cover in the 2003 site. According to Figueroa and Jaksic (2004) and Figueroa et al. (2004), there is a limited dispersion of grass seed in mature successional ecosystems because under a continuous canopy neither pasture establishments nor propagules are maintained on the ground.

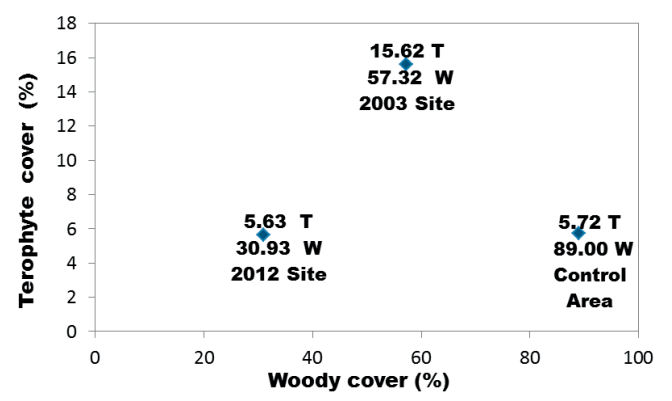

Figure 4. Therophyte cover and woody vegetation cover in percentages.
The correlation between therophyte and woody species was $r=-0.19$; therefore, there is no significant relationship between these plant types $(\mathrm{P}=0.6307)$. Likewise, no significant correlation was identified between geophyte and therophyte species $(\mathrm{r}=-0.39411 ; \mathrm{P}=0.2939)$.

\section{Biomass of geophyte species}

Significant differences were found when the aerial biomass and the underground biomass of geophytes were analyzed in the three study sites $(\mathrm{P}=0.0066)$ (Table 2).

Table 2. Aerial and underground biomass of geophyte species $\left(\mathrm{g} \mathrm{m}^{-2}\right)$.

\begin{tabular}{llll}
\hline Sites studied & Aerial & Underground & $\begin{array}{l}\text { Average total } \\
\text { sites }\end{array}$ \\
\hline 2012 & $39.51 \mathrm{bA}$ & $147.92 \mathrm{bB}$ & 93.71 \\
2003 & $8.79 \mathrm{aA}$ & $77.39 \mathrm{aB}$ & 43.09 \\
Control & $11.50 \mathrm{aA}$ & $59.03 \mathrm{aB}$ & 35.26 \\
$\begin{array}{l}\text { Total average } \\
\text { biomass }\end{array}$ & 19.93 & 94.78 & 57.35 \\
\hline
\end{tabular}

Capital letters compare differences between aerial and underground biomass, and small letters compare differences between sites. Tukey test $(\mathrm{P} \leq 0.05)$.

There were significant differences between the aerial and underground biomasses of the three sites studied, and the belowground biomass was always greater than the aerial biomass $(\mathrm{P} \leq 0.0001)$ (Table $2)$. The greatest overall biomass was produced in the site burned by fire in $2012(\mathrm{P} \leq 0.05)$.

According to Ávila et al. (1981), the biomass values in burned areas in Chile are higher than in the control sites, especially during the ecological recovery in the first year after the fire. Ávila et al. (1981) indicate that the level of nitrogen in burned sites is higher than in control sites. Anderson and Bailey (1980) attribute the biomass increase found in sites restored after fires to the increase of organic matter and phosphorus in these environments. This increase in organic matter and phosphorus could explain the increase of aerial and underground biomass of geophyte species at the 2012 site. 
There was a significant difference between the underground biomass of Oziroe arida compared to other species (Table 3) in the 2012 site and the control site.

Of all the species analyzed in the three study sites, only Oziroe arida presented a significant difference in underground biomass between the 2012 and control sites. However, this species is not significantly different between the 2003 site and the control site.

Based on the anatomy of the Oziroe arida bulbs, several axillary buds were observed leading to the quick regrowth of underground stems after the fire of 2012. This would explain the significant differences in the belowground biomass of this species at the site of the 2012 fire compared to the site of the 2003 fire, and the control.

\section{Bulb age of Oziroe arida}

The regression analysis determined that there is an increase of 2.99 years of age for each millimeter of bulb diameter in Oziroe arida $\left(\mathrm{R}^{2}=0.7848\right)$ (Figure 5). Therefore, bulb diameter could be used as an age indicator.

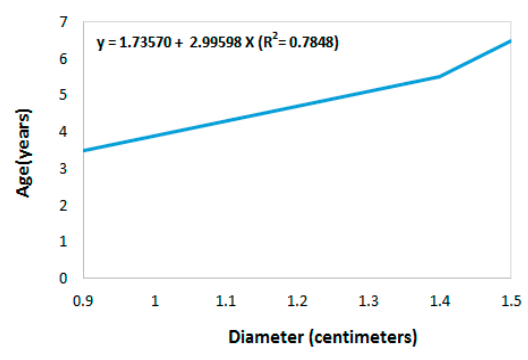

Figure 5. Diameter and age of 25 Oziroe arida bulbs.
Oziroe arida was also described by Montenegro et al. (2003), and among geophytes, it was found to have higher survival rates after a fire in the coastal matorral of Chile.

Geophytes survive fires because their bulbs, corms, or rhizomes are buried deep enough to protect them from the high temperatures of the soil surface (Keeley and Keeley, 1988; Montenegro et al., 2003; Montenegro et al., 2004). Storage organs such as bulbs can protect against the negative effects of disturbances such as fires, and can improve population persistence over time in those plant species that live in these Mediterranean environments (García and Zamora, 2003).

Geophytes cannot compete with the dominant shrub vegetation; therefore, they must find optimal growing conditions after a fire. Blooming is supported by stored carbohydrates, and a high number of seeds are produced in the first year after a fire. The subsequent post fire years are the best time for seedling recruitment, and refractory seeds do not develop in this type of environment. Geophyte bulbs, corms and tubers must persist in a dormant state until a fire occurs (Keeley, 1995).

The results of this study support the conclusion that the life cycle of geophytes is closely related to the coverage of woody species. Therefore, the action of fire would favor the regeneration of geophytes through proliferation and reproduction, allowing them to take advantage of an environment in which competition with woody vegetation has been reduced or eliminated.

Table 3. Dry underground biomass of the four geophyte species $\left(\mathrm{g} \mathrm{m}^{-2}\right)$ with the highest biomass in the sites studied.

\begin{tabular}{llllll}
\hline Sites studied & $\begin{array}{l}\text { Conanthera } \\
\text { trimaculata }\end{array}$ & $\begin{array}{l}\text { Dioscorea } \\
\text { humifusa }\end{array}$ & Oziroe arida & Pasithea caerulea & Average per site \\
\hline 2012 & $9.84 \mathrm{aA}$ & $8.72 \mathrm{aA}$ & $82.87 \mathrm{bB}$ & $10.19 \mathrm{aA}$ & 27.90 \\
2003 & $17.82 \mathrm{aA}$ & $8.8 \mathrm{aA}$ & $24.69 \mathrm{aA}$ & $12.38 \mathrm{aA}$ & 15.92 \\
$\begin{array}{l}\text { Control } \\
\begin{array}{l}\text { Average per } \\
\text { species }\end{array}\end{array}$ & $12.19 \mathrm{aA}$ & $6.48 \mathrm{aA}$ & $24.00 \mathrm{aB}$ & $9.26 \mathrm{aA}$ & 12.98 \\
\hline
\end{tabular}

Capital letters compare different species and small letters compare differences between sites. Tukey test $(\mathrm{P} \leq 0.05)$. 
During their life cycle, the bulbs are fire-dependent because when the soil is open, geophytes will grow and reproduce. However, with increasing shrub cover, geophytes will become dormant, and this can last for many years until another fire occurs. Therefore, geophytes can reproduce and generate offspring only when released from the shadows of shrub vegetation coverage(i.e., when there is fire occurrence).

\section{Resumen}

\section{P. Sabadin, M. Gómez, R. Ginocchio, I. Peña y G. Montenegro. 2015. Efecto de los} incendios en la vegetación herbácea "matorral", en Chile Central. Inv. Agr. 42(3): 415-425. La investigación tuvo por objetivo determinar la diversidad y la biomasa de especies existentes en sitios incendiados en distintos años, en el Jardín Botánico Nacional de Viña del Mar, Región de Valparaíso, Chile (Lat. $33^{\circ} 02^{\prime} \mathrm{S}$ y Long. $71^{\circ} 35^{\prime} \mathrm{O}$ ) de abril a diciembre de 2012. Se seleccionaron tres sitios, en áreas ubicadas en laderas con la misma exposición: 1) Sitio quemado por un incendio en 2012; 2) Sitio quemado por un incendio en 2003; 3) Sitio control, correspondiente a un área sin ocurrencia de incendios anteriores. Se estudiaron tanto las especies arbustivas como las especies herbáceas. La cobertura de arbustos, geófitas y terófitas se determinó así como la biomasa aérea y subterránea de geófitas, con especial atención en Oziroe árida, en la que, se estudió el diámetro de sus bulbos. Toda la información fue procesada través de programa computacional SAS, con ANOVA - análisis de 2 VIAS de clasificación. En el sitio quemado por el incendio de 2012, se encontró un mayor porcentaje de cobertura de geófitas que se basa en el aumento de la regeneración post-incendio de esta forma de vida. La biomasa de geófitas fue mayor en los sitios quemados, especialmente durante la recuperación en el primer año después del fuego (sitio de 2012). En el sitio de 2003, ocurrió un mayor porcentaje de cobertura de terófitas; la cobertura de terófitas no se explica en función de la cobertura de leñosas. Se estimó que cada $\mathrm{mm}$ de diámetro de los bulbos de Oziroe arida, la geófita más abundante en el sitio 1 , significa 2,99 años de edad de la planta $\left(\mathrm{R}^{2}=0,78\right)$, considerando el diámetro como un indicador de la edad de los bulbos. El estudio representa el primero en el país que realiza un análisis cuantitativo del comportamiento de geófitas después de incendios (biomasa aérea y subterránea), concluyendo que la acción del fuego favorecería la regeneración de geófitas, a través de la generación de una mayor biomasa aérea y subterránea, generando condiciones para un aumento de la reproducción.

Palabras clave: Biomasa aérea, biomasa subterránea, cobertura, especies arbustivas, geófitas,

incendios, Oziroe arida, terófitas.

\section{References}

Anderson, H.G., and A.W. Bailey. 1980. Effects of annual burning on grassland in the aspen parkland of east-central Alberta. Can. J. Bot. 58:985-996.

Araya, S. and G. Ávila. 1981. Rebrote de arbustos afectados por fuego en el matorral chileno. Anales del Museo de Historia Natural de Valparaíso 14: 107-113.
Arroyo, M.K. and L. Cavieres. 1997. The mediterranean-type climate flora of Central Chile - What do we know and how can we assure its protection. Noticiero de Biología 5 (2): 48-56.

Ávila, G., M. Aljaro, and B. Silva. 1981. Observaciones en el estrato herbáceo después del fuego. Anales del Museo de Historia Natural de Valparaíso 14:99-105.

Blair, J.M. 1997. Fire, N availability, and plant response in grasslands: a test of the transient maxima hypothesis. Ecology 78:2359-2368.

Diadema, K., F. Medail, and F. Bretagnolle. 2007. Fire as a control agent of demographic structure and plant performance of a rare Mediterranean 
endemic geophyte. Comptes-Rendus Biologies 330:691-700.

Di Castri, F. 1981. Mediterranean-type shrublands of the world. In: F. di Castri, D.W. Goodall and R.L. Spech (eds.). Mediterranean-Type Shrublands. Amsterdan, Elservier. p. 1-52.

Fernández, I, N. Morales, L. Olivares, J. Salvatierra, M. Gómez, and G. Montenegro. 2010. Restauración ecológica para ecosistemas nativos afectados por incendios forestales, Santiago, Chile, Gráfica LOM. 162 pp.

Figueroa, J.A., and F.M. Jaksic. 2004. Seed bank and dormancy in plants of the Mediterranean region of central Chile. Revista Chilena de Historia Natural 77:201-215.

Figueroa, J.A., S. Teillier, and F.M. Jaksic. 2004. Composition, size and dynamics of the seed bank in a mediterranean shrubland of Chile. Austral Ecology 29:574-584.

Figueroa, J.A., L.A. Cavieres, S. Gomez-Gonzalez, M.A. Molina-Montenegro, and F.M. Jaksic. 2009. Do heat and smoke increase emergence of exotic and native plants in the matorral of central Chile? Acta Oecologica-International Journal of Ecology 35:335-340.

García, D., and R. Zamora. 2003. Persistence, multiple demographic strategies and conservation in long-lived Mediterranean plants. Journal of Vegetation Science 14: 921-926.

Groves, R.H. and Di Castri, F. 1991. Biogeography of Mediterranean Invasions. Cambridge, Cambridge University Press. 485 pp.

Hoffmann, A.J., F. Liberona, and A.E. Hoffmann. 1998. Distribution and ecology of geophytes in Chile. Conservation threats to geophytes in mediterranean-type regions. In: Rundel, P.W., Montenegro, G., and Jaksic, F.M. (eds.). Landscape degradation and biodiversity in Mediterranean-type ecosystems. Berlin: Springer. p. 231-253.

Jiménez, H.E., and J.J. Armesto. 1992. Importance of the soil seed bank of disturbed sites in Chilean matorral in early secondary succession. Journal of Vegetation Science 3: 579-586.

Johnson, K.A., D.A. Morrison, and G. Goldsack. 1994. Postfire flowering patterns in Blandfordia nobilis (Liliaceae). Australian Journal of Botany 42: 49-60.

Keeley, S.C., J.E. Keeley, S.E. Hutchinson, and A.W. Johnson. 1981. Postfire succession of the herbaceaous flora in southern California chaparral. Ecology 62: 1608-1621.

Keeley, J.E., and S. Keeley. 1986. Chaparral and wildfires. Fremontia (United States) 14: 18-21.

Keeley, J.E., and S.C. Keeley. 1988. Chaparral. In: Barbour M.G. and Billings W.D. (eds.). North American Terrestrial Vegetation. Cambridge University Press, Cambridge. p. 165-207.

Keeley, J.E. 1993. Smoke-induced flowering in the fire-lily Cyrtanthus ventricosus. S. Afr. J. Bot. 59: 638 .

Keeley, J.E. 1995. Seed germination patterns in fire-prone Mediterranean- climate regions. In: Arroyo, M.T.K., P.H. Zedler, M.D. Fox (eds.). Ecology and Biogeography of Mediterranean Ecosystems in Chile, California and Australia, Springer-Verlag, New York. p. 239-273.

Kent, M, and P. Coker. 1994. Vegetation description and analysis: a practical approach. Chichester: John Wiley \& Sons, England. 363 pp.

Le Maitre, D.C., and J.J. Midgley. 1992. Plant reproductive ecology, In: R.M. Cowling (ed.). Fynbos, Nutrients, Fire and Diversity, Oxford University Press, Cape Town. p. 135-174.

Luebert, F., and P. Pliscoff. 2005. Sinopsis Bioclimática y Vegetacional de Chile. Editorial Universitaria. Santiago, Chile. 316 pp.

Matthei, O. 1995. Manual de las Malezas que Crecen en Chile. Alfabeta Impresores Ltda., Santiago, Chile.

Montenegro, G. 2000. Chile, nuestra flora útil. Guía de uso apícola, medicinal, folclórica, artesanal y ornamental. Ediciones Universidad Católica de Chile. Santiago, Chile.

Montenegro, G. 1986. Potencial de uso, capacidad y velocidad de regeneración de especies vegetales de ecosistemas árido-andinos de Chile. Ambiente y Desarrollo 2:147-153.

Montenegro, G. 1984. Anatomía de especies vegetales autóctonas de la Zona Central. Ediciones Universidad Católica. Santiago, Chile. 156 pp.

Montenegro, G. 1974. Desarrollo de raíces contrác- 
tiles en Hippeastrum chilense, geófita del matorral chileno. Acta Científica Venezolana 25:82-86.

Montenegro, G., and R. Ginocchio. 1995. Ecomorphological Characters as a Resource for Illustrating Growth-form Convergence in Chaparral and Mallee. In: Kalin Arroyo M.T., Zedler P.H., and Fox M.D. (eds.). Ecology and Biogeography of Mediterranean Ecosystems in Chile, California and Australia. NY, Springer Verlag. p. 160-176.

Montenegro, G., R. Ginocchio, A. Segura, J. Keeley, and M. Gómez. 2004. Fire regimes and vegetation responses in two Mediterranean-climate regions. Revista Chilena de Historia Natural 77: 455-464.

Montenegro G., F. Díaz, M. Gómez, and R. Ginocchio. 2003. Regeneration potential of Chilean matorral after fire: an updated view. In: Veblen T., Baker W., Montenegro G. and Swetnam T. (eds.). Fire and climate change in temperate ecosystems of the western Americas. New York, USA, Springer-Verlag. p. 375-403.

Montenegro, G., G. Ávila, and P. Schatte. 1983. Presence and development of lignotubers in shrubs of the Chilean matorral. Canadian Journal of Botany 61(6): 1804-1808.

Montenegro G., B. Segura, R. Saenger, and A.M. Mujica. 1981. Xeromorfismo en especies arbustivas del matorral chileno. Annales del Museo de Historia Natural 14:71-83.

Mostacedo, B. and T.S. Fredericksen. 2000. Manual de Métodos Básicos de Muestreo y Análisis en Ecología Vegetal. Editora El País. Santa Cruz, Bolivia.

Mooney, H.A. (ed.). 1977. Convergent evolution of Chile and California Mediterranean climate ecosystems. Dowden, Hutchinson \& Ross, Strouds- burg, Pennsylvania, USA.

Muñoz, M.R., and E.R. Fuentes. 1989. Does fire induce shrub germination in the Chilean matorral? Oikos 56:177-181.

Myers, J., R. Mittermeier, C. Mittermeier, D. Fonseca, and J. Kent. 2000. Biodiversity hotspots for conservation priorities. Nature 403: 853-858.

Parker, V.T., and V.R. Kelly. 1989. Seed banks in California chaparral and other Mediterranean climate shrublands. In: Leck M.A., Parker V.T. and Simpson R.L. (eds.). Ecology of Soil Seed Banks. Academic Press, San Diego. p. 231-255.

Rundel, P.W. 1981. Fire as an ecological factor. In: Lange, O.L., P.S. Nobel, C.B. Osmond, and H. Ziegler (eds.). Physiological Plant Ecology I: 501-538. Springer-Verlag, New York, New York, USA.

Rundel, P. 1998. Landscape Disturbance in Mediterranean-Type Ecosystems: An overview. In: Rundel, P., Montenegro, G. and Jaksic, F. (eds.). Landscape Degradation and Biodiversity in Mediterranean-Type Ecosystems, p. 3-18. Ecological Studies vol 136, Berlin Heidelberg, Springer-Verlag.

Stone, E.C., and G. Juhren. 1951. The effect of fire on the germination of the seed of Rhusovata Wats. Am. J. Bot. 38:368-372.

Tyler, C. and M. Borchert. 2002. Reproduction and growth of the chaparral geophyte, Zigadenus fremontii (Liliaceae), in relation to fire. Plant Ecology 165: 11-20.

Villaseñor, R., and F. Sáiz. 1990. Incendios forestales en el Parque Nacional La Capana, Sector Ocoa, V Región, Chile. III. Efecto sobre el estrato herbáceo. Anales Museo Historia Natural 21:27-32. 
Wells, P.V. 1969. The relation between mode of reproduction and extend of speciation in woody genera of the California chaparral. Evolution 23:264-267. 